\title{
ANALISIS FAKTOR-FAKTOR YANG MEMPENGARUHI EFISIENSI PRODUKSI BENIH IKAN PATIN (STUDI KASUS PANDAWA LIMA FISHERIES FARM BOGOR)
}

\author{
Adam Purnama, Lilis Imamah Ichdayati* dan Rahmi Purnomowati
}

\begin{abstract}
ABSTRAK
Tujuan dari penelitian ini adalah; (1) untuk menentukan faktor yang mempengaruhi produksi benih ikan lele di Pandawa Lima Fisheries Farm Bogor, (2) untuk menentukan elastisitas produksi benih ikan patin di Pandawa Lima Fisheries Farm Bogor, dan (3) untuk menentukan tingkat teknis efisiensi operasi pembenihan ikan lele di Pandawa Lima Fisheries Farm Bogor. Analisis R / C digunakan untuk menganalisis pendapatan produksi benih lele selama 30 siklus produksi. Hasil penelitian menunjukkan bahwa pendapatan usahatani positif dengan nilai Rp 851,343.75 per siklus. Nilai R/C adalah 1,12 menunjukkan bahwa penetasan ikan patin di Pandawa Lima Fisheries Farm Bogor dianggap menguntungkan dan layak dikembangkan.
\end{abstract}

Kata kunci: produksi, pendapatan, lele, $R / C$

\begin{abstract}
The objectives of this research are; (1) to determine the factors effecting seed production of catfish in the Pandawa Lima Fisheries Farm Bogor, (2) to determine the elasticity of seed production of catfish in the Pandawa Lima Fisheries Farm Bogor, and (3) to determine the level of technical efficiency on hatchery operations of catfish in Pandawa Lima Fisheries Farm Bogor. The R/C analysis was employed to analyze income of catfish seed production for 30 cycles of production. Results showed that farm income is positive with a value of Rp 851,343.75 per cycle. The $R / C$ value was 1.12 indicated that catfish hatcheries in Pandawa Lima Fisheries Farm is considered advantageous to cultivate.
\end{abstract}

Keywords :production, income, catfish, $R / C$ 


\section{PENDAHULUAN}

Menurut UU RI nomor 45 tahun 2009 tentang perubahan atas UU Nomor31 tahun 2004 menyatakan bahwa perikanan adalah semua kegiatan yang berhubungan dengan pengelolaan dan pemanfaatan sumber daya ikan dan lingkungannya mulai dari praproduksi, produksi, pengolahan sampai dengan pemasaran yang dilaksanakan dalam suatu sistem bisnis perikanan. Puspita dan Wiyono (2014:1) menyatakan bahwa bisnis pada sektor perikanan merupakan salah satu bisnis yang sangat menjanjikan. Selain karena kebutuhan pasokan pangan yang sangat tinggi, bisnis pada sektor perikanan juga berkembang baik sejalan dengan perubahan pola pikir masyarakat untuk lebih sehat. Hal ini dapat dilihat dari meningkatnya volume produksi perikanan dari tahun ke tahun.

Data statistik Kementerian Kelautan dan Perikanan (2014:1) menunjukkan bahwa volume produksi perikanan nasional mengalami sejumlah peningkatan dari tahun ke tahun. Tingkat produksi perikanan nasional dapat dilihat pada Gambar 1. Tingkat volume produksi di bidang perikanan tahun 2014 berjumlah sekitar 6,2 juta ton, sedangkan tingkat produksi perikanan nasional pada tahun 2005 kembali meningkat sekitar 6,9 juta ton hingga tahun 2012 tingkat produksi di sektor tersebut mencapai 15,2 juta ton. Laju pertumbuhan rata-rata produksi perikanan nasional tahun 20042012 mencapai $12.19 \%$ setiap tahunnya. Hal ini dikarenakan adanya kesadaran masyarakat yang semakin meningkat mengenai pentingnya mengkonsumsi ikan untuk memenuhi kebutuhan gizinya. Masyarakat lebih cenderung memilih komoditas perikanan karena lebih aman untuk dikonsumsi. Kandungan ikan kaya akan manfaat, seperti hal nya sebagai sumber protein bagi tubuh.

Puspita dan Wiryono (2014:1) menyatakan bahwa salah satu bisnis perikanan unggulan di Indonesia adalah ikan patin. Ikan patin merupakan jenis ikan konsumsi air tawar, berbadan panjang dan berwarna putih perak dengan punggung berwarna kebiru-biruan. Ikan patin juga merupakan komoditas yang bernilai ekonomi tinggi karena memiliki harga jual yang tinggi serta dibutuhkan oleh masyarakat secara terus menerus. Usaha budidaya patin memiliki risiko yang lebih ringan dibandingkan budidaya ikan air tawar lainnya. Selain itu, usaha budidaya patin juga tidak memerlukan teknologi tinggi, sehingga semua orang dapat membudidayakannya. Dalam laporan tahunan Direktorat Jenderal Perikanan Budidaya Nasional (2014:11) menyatakan bahwa produksi ikan patin dalam negeri pada tahun 2009 mencapai 109.685 ton. Pada tahun 2013 produksi ikan patin meningkat secara signifikan hingga mencapai 972.778 ton dan memiliki nilai presentase kenaikan rata-rata produksi sebesar 95,57 \% setiap tahunnya.

Saat ini sudah banyak yang menggeluti usaha bisnis budidaya patin tersebut. Salah satunya adalah Pandawa Lima Fisheries Farm yang terletak di Kabupaten Bogor. Pandawa Lima Fisheries Farm memilih untuk mengembangkan jenis usaha pembenihan ikan patin. Hal ini dikarenakan jangka waktu pemanenan pembenihan ikan patin lebih cepat dibandingkan dengan pembesaran ikan patin, sehingga pendapatan yang diperoleh dari pembenihan ikan patin juga lebih cepat dibandingkan dengan melakukan pembesaran ikan patin tersebut. Namun, Pandawa Lima Fisheries Farm belum dapat memproduksi benih ikan patin secara massal, dikarenakan jumlah produksi yang 
dihasilkan cenderung naik turun atau fluktuatif, sehingga penjualan benih ikan patin kepada konsumen masih sangat terbatas.

Hasil produksi benih patin yang dihasilkan Pandawa Lima Fisheries Farm sejalan dengan jumlah pendapatan yang diterima. Hal ini dikarenakan jumlah pendapatan benih patin di perusahaan dipengaruhi oleh jumlah benih patin yang dihasilkan tiap siklusnya. Benih patin di Pandawa Lima Fisheries Farm Bogor memiliki nilai jual $\mathrm{Rp} 60$ dan mengalami penurunan pada awal Januari 2014 menjadi Rp 55 per ekornya. Penurunan harga jual benih patin dikarenakan harga benih patin di perusahaan mengikuti harga di pasaran.

Konsumen di daerah Jawa Barat menjadi tujuan utama Pandawa Lima Fisheries Farm dalam mendistribusikan benih patin. Berdasarkan survei BPS (2015:1), tingkat konsumsi ikan di Jawa Barat mencapai $23 \mathrm{~kg} / \mathrm{kapita}$ di tahun 2012. Kemudian tingkat konsumsi ikan meningkat menjadi $24 \mathrm{~kg} / \mathrm{kapita}$ pada tahun 2013. Selanjutnya, tingkat konsumsi ikan di Jawa Barat meningkat hingga mencapai 27,5 kg/kapita. Berdasarkan laporan perkembangan produksi dan pendapatan benih ikan patin Pandawa Lima Fisheries Farm serta tingkat konsumsi ikan di Jawa Barat, maka perlu ada penanganan khusus guna menyelesaikan masalah tersebut. Salah satu langkah yang harus dilakukan adalah dengan mengidentifikasi faktor-faktor produksi benih ikan patin.

\section{METODE PENELITIAN}

\section{Lokasi dan Waktu Penelitian}

Penelitian ini dilaksanakan di tempat produksi pembenihan ikan patin, yaitu Pandawa Lima Fisheries Farm yang berlokasi di Kampung Mangga Dua RT/RW 03/01, No 2 Desa Suka Damai Kab. Bogor,
Provinsi Jawa Barat. Pengumpulan data penelitian dilakukan pada bulan Desember 2014.

\section{Jenis dan Sumber Data}

Data yang digunakan dalam penelitian ini adalah data primer dan data sekunder, yang bersifat kualitatif maupun kuantitatif. Data primer diperoleh dari wawancara langsung dengan pemilik Pandawa Lima Fisheries Farm Bogor melalui kuisioner yang telah disiapkan untuk mengetahui karateristik perusahaan, penggunaan input, serta faktor-faktor produksi yang mempengaruhi pembenihan ikan patin, sedangkan data sekunder diperoleh dari laporan produksi Pandawa Lima Fisheries Farm untuk setiap siklus secara deret waktu (Time Series) dari bulan Juli 2012 Desember 2014. Data yang digunakan dalam penelitian sebanyak 30 siklus meliputi jumlah produksi benih patin, jumlah penggunaan input, serta total penerimaan dan biaya dalam pembenihan ikan patin di perusahaan.

\section{Metode Pengambilan Sampel}

Teknik pengambilan sampel pada penelitian ini menggunakan metode Purposive Sampling. Sampel yang digunakan dalam penelitian ini adalah produksi benih ikan patin, sedangkan jumlah sampel yang digunakan dalam penelitian ini adalah 30 sampel produksi benih patin. Jumlah tersebut sudah memenuhi syarat dari suatu metode penelitian yaitu minimal 30 sampel.

\section{Analisis Data}

Untuk menjawab tujuan dari penelitian ini menggunakan perangkat lunak Microsoft Excell 2007 dan dilakukan pengolahan data dengan menggunakan perangkat lunak SPSS 16 dan Frontier 4.1. SPSS 16 digunakan untuk mengetahui uji asumsi 
klasik linier pada data penelitian, sedangkan Frontier

4.1 digunakan untuk mengetahui estimasi nilai parameter dari Maximum Likehood Estimated dalam fungsi produksi CobbDouglas Stochastic Frontier. Data yang sudah diolah, kemudian dianalisis dengan dua cara yaitu secara kualitatif dan kuantitatif. Data kuantitatif yang telah diolah disajikan dalam bentuk tabel, sedangkan data kualitatif dipaparkan dalam bentuk uraian guna mendukung data kuantitatif yang tersedia sebelumnya.

\section{Uji Asumsi Klasik Linier}

Ghozali (2005:110) menjelaskan bahwa uji normalitas bertujuan untuk menguji apakah dalam model regresi, variabel pengganggu atau residual memiliki distribusi normal. Kriteria pengambilan keputusan adalah apabila nilai signifikasi atau probabilitas $>0,05$ maka residual memilki distribusi normal dan apabila nilai signifikasi atau probabilitas $<0,05$, maka residual tidak memiliki distribusi normal. Ghozali (2005:91) menjelaskan bahwa uji multikolineritas bertujuan untuk menguji apakah model regresi ditemukan adanya korelasi antar variabel bebas (independen). Model regresi yang baik seharusnya tidak terjadi korelasi diantara variabel independen.

Ghozali (2005:105) menjelaskan bahwa uji heteroedastisitas bertujuan untuk menguji apakah dalam model regresi terjadi ketidaksamaan variance dari residual satu pengamatan ke pengamatan lain. Cara mendeteksi ada atau tidaknya heterokedastisitas adalah dengan melihat grafik plot antara nilai prediksi variabel dependen. Ghozali (2005:95) menjelaskan bahwa uji autokorelasi bertujuan untuk mengetahui apakah dalam model regresi linear ada korelasi antara kesalahan pengganggu pada periode $t$ dengan kesalahan pengganggu pada periode $\mathrm{t}-1$.
Cara yang dapat dilakukan untuk mendeteksi ada atau tidaknya autokorelasi adalah dengan melakukan uji Durbin Watson.

\section{Efisiensi Teknis dan In-efisiensi Teknis}

Efisiensi teknis pada penelitian ini menggunakan fungsi produksi CobbDouglas dengan metode Stochastic Frontier. Metode stochastic frontier merupakan salah satu metode yang dapat digunakan untuk mengukur tingkat efisiensi relatif suatu usahatani. Pada fungsi produksi Cobb-Douglas Stochastic frontier menggunakan parameter pendugaan Ordinary Least Square (OLS) metode ini menunjukan gambaran kinerja rata-rata (Best Fit) dari produksi pembenihan ikan patin di Pandawa Lima Fisheries Farm Bogor pada tingkat teknologi yang ada. Sedangkan Maximum Likehood Estimated (MLE) metode ini digunakan untuk mengetahui parameter pendugaan pembenihan ikan patin di Pandawa Lima Fisheries Farm Bogor melalui pengolahan yang baik (Best Practice). Faktor-faktor yang mempengaruhi produksi pembenihan ikan patin di Pandawa Lima Fisheries Farm Bogor adalah larva patin (X1), cacing sutera (X2), berat induk patin (X3) dan tenaga kerja (X4). Model dugaan yang dilakukan dalam penelitian ini, dirumuskan dalam persamaan berikut:

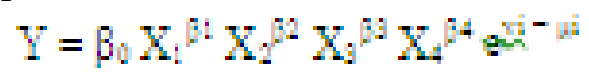




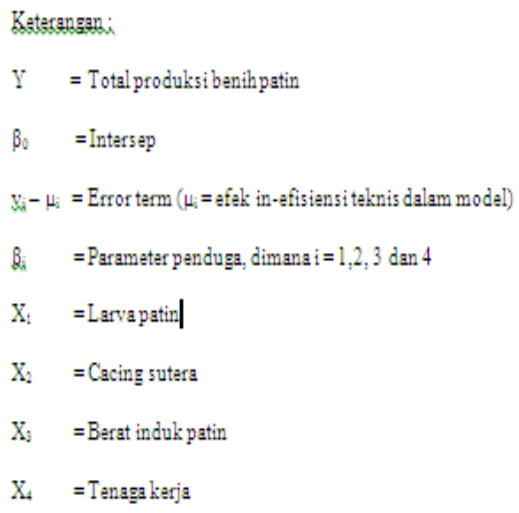

Faktor-faktor yang mempengaruhi tingkat in-efisiensi teknis pembenihan patin dalam penelitian ini adalah survival rate benih patin (Z1), jumlah induk patin (Z2), rata-rata umur pekerja (Z3), rata-rata pengalaman pekerja (Z4) dan rata-rata pendidikan pekerja (Z5). Dengan demikian parameter distribusi efek in-efisiensi pada pembenihan ikan patin adalah:

$$
\begin{aligned}
& \mu_{i}=\partial_{0}+\partial_{i} Z_{i}+\partial_{2} Z_{2}+\partial_{3} Z_{3}+\partial_{4} Z_{4}+\partial_{3} Z_{3}+W_{j} \\
& \text { dimana: } \\
& \mu_{i}=\text { Nilai in-efisiensi } \\
& \partial_{0}=\text { Koefisien inters ep } \\
& \partial=\text { Parameter peubah ke } 1.2 .3,4 \text { dan } 5 \\
& Z_{2}=\text { Sunvival vate benih patin } \\
& Z_{2}=\text { Jumlah induk patin } \\
& Z_{3}=\text { Rata- rata umur pekerja } \\
& Z_{4}=\text { Rata- rata pengalaman pekerja } \\
& Z_{3}=\text { Rata-rata pendidikan pekerja }
\end{aligned}
$$

\section{Elastisitas Produksi}

Analisis elastisitas produksi dapat diketahui dengan melihat nilai koefisien regresi pada fungsi produksi Cobb-Douglas. Hasil pendugaan garis melalui fungsi CobbDouglas akan menghasilkan koefisien regresi dan juga menunjukan besaran elastisitas. Nilai total besaran elastisitas dari setiap variabel dapat menunjukan nilai skala pengembalian usaha (Return To Scale).

\section{Definisi Operasional}

1. Total produksi (Y) adalah jumlah ekor benih patin yang dihasilkan dalam satu siklus dengan umur 2025 hari (Ekor).

2. Larva patin (X1) adalah jumlah larva patin yang menetas dari telur patin yang telah ditaruh pada akuarium untuk dipelihara menjadi benih patin yang siap dipanen. Satuannya adalah jumlah larva setiap 1 siklus (Ekor).

3. Cacing sutera (X2) adalah pakan yang digunakan sebagai makanan larva patin ketika larva patin sudah memasuki umur 10 hari. Satuannya adalah gram (g).

4. Berat induk patin (X3) adalah jumlah indukan betina dan jantan per $\mathrm{kg}$ yang digunakan dalam proses pembenihan ikan patin dalam 1 siklus. Satuan yang digunakan adalah kilogram $(\mathrm{kg})$

5. Tenaga kerja (X4) adalah jumlah tenaga kerja yang dibutuhkan dalam produksi benih ikan patin dalam 1 siklus. Satuannya adalah jumlah orang yang digunakan (Orang).

6. Survival rate (Z1) adalah hasil persentase antara jumlah produksi benih dan jumlah larva yang menetas dalam satu siklus. Satuannya adalah jumlah persen yang dihasilkan (\%).

7. Jumlah induk (Z2) adalah jumlah indukan patin yang digunakan dalam pembenihan ikan patin di Pandawa Lima Fisheries Farm. Satuannya adalah indukan patin per ekor (Ekor).

8. Rata-rata umur pekerja (Z3) adalah tingkat rata-rata umur pekerja yang bekerja di Pandawa Lima Fisheries Farm Bogor. Satuannya adalah tahun.

9. Rata-rata pengalaman pekerja (Z4) adalah tingkat rata-rata lama pengalaman yang dimiliki oleh para 
pekerja dalam pembenihan ikan patin di Pandawa Lima Fisheries Farm Bogor. Satuannya adalah tahun.

10. Rata-rata pendidikan pekerja (Z5) adalah tingkat rata-rata lama pendidikan yang dimiliki oleh para pekerja di Pandawa Lima Fisheries Farm Bogor. Satuannya adalah tahun.

\section{HASIL DAN PEMBAHASAN}

\section{Elastisitas Produksi dan Skala Usaha Benih Ikan Patin}

Hasil elastisitas produksi dapat dilihat dari nilai koefisien regresi yang terdapat pada fungsi produksi Cobb-Douglas melalui pendekatan Stochastic Frontier. Variabel independen yang digunakan dalam penelitian ini adalah larva patin, cacing sutera, berat induk patin dan tenaga kerja. Pendugaan parameter pada fungsi produksi Cobb-Douglas Stochastic Frontier ini dilihat dari metode MLE (Maximum Likehood Estimated). Metode Maximum Likehood Estimated dapat menggambarkan kinerja terbaik (best practice) dari Pandawa Lima Fisheries Farm Bogor dalam melakukan pembenihan ikan patin.

Berdasarkan hasil perhitungan model fungsi produksi Cobb-Douglas Stochastic Frontier yang dilakukan dengan menggunakan perangkat lunak Frontier 4.1, diperoleh hasil pendugaan parameter yang tercantum pada Tabel 1.

\begin{tabular}{|c|c|c|}
\hline Variabel & Koefisien & t-hitung \\
\hline Intersep & $-0,23$ & $-6,85^{*}$ \\
\hline Larva Patin $\left(\mathrm{X}_{\mathrm{I}}\right)$ & 1,002 & $343,95^{*}$ \\
\hline Cacing Sutera $\left(\mathrm{X}_{2}\right)$ & $-0,0049$ & $2,58^{* *}$ \\
\hline Berat Induk $\left(X_{3}\right)$ & 0,0307 & $2,46^{* * * *}$ \\
\hline Tenaga Kerja $\left(\mathrm{X}_{4}\right)$ & 0,019 & $1,08^{* * * * *}$ \\
\hline Sigma-Squared & \multicolumn{2}{|c|}{0,000000097} \\
\hline Gamma & \multicolumn{2}{|c|}{0,91} \\
\hline 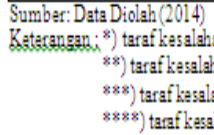 & & \\
\hline
\end{tabular}

Berdasarkan hasil pendugaan Tabel 1 dapat dilihat bahwa nilai gamma sebesar 0,91 yang mengindikasikan bahwa $91 \%$ dari error term yang berada dalam fungsi produksi dikarenakan oleh in-efisensi teknis, sedangkan sisanya yaitu $9 \%$ dikarenakan oleh variabel kesalahan acak.

\section{Efisiensi Teknis dan In-Efisiensi Benih Ikan Patin}

Tabel2. SebaranNilai Efisiensi Teknis Produksi Benih Patin Pandawa Lima Fisheries Farm

\begin{tabular}{|c|c|c|}
\hline Tingkatan Efisensi Teknis & Jumlah siklus & Persentase \\
\hline TE $<0,5$ & 9 & 30 \\
\hline $0,5<\mathrm{TE}<0,6$ & 1 & 3 \\
\hline $0,6<\mathrm{TE}<0,7$ & 1 & 3 \\
\hline $0,7<\mathrm{TE}<0,8$ & 10 & 20 \\
\hline $0,8<\mathrm{TE}<0,9$ & 6 & 10 \\
\hline TE $>0,9$ & 3 & 100 \\
\hline Total & 30 & 0,66 \\
\hline Rata-rata TE & \multicolumn{2}{|c|}{0,33} \\
\hline Minimum TE & \multicolumn{2}{|c|}{0,99} \\
\hline Maksimum TE & \multicolumn{2}{|c|}{} \\
\hline & & \\
\hline Sumber: Data Diolah(2014) & & \\
\hline
\end{tabular}

Berdasarkan tabel 2, tingkat efisiensi teknis Pandawa Lima Fisheries Farm berada pada range 0,33 hingga 0,99 . Nilai minimum efisiensi teknis pada perusahaan 
sebesar 0,33 sedangkan nilai maksimum efisiensi teknis pada penelitian ini adalah sebsar 0,99 . Nilai mean efficiency atau nilai rata-rata efisiensi teknis pada produksi patin di Pandawa Lima Fisheries Farm sebesar 0,66 atau tingkat efisiensi teknisnya sebesar $66 \%$.

Kemudian dilakukan penghitungan inefisiensi teknis pada pembenihan ikan patin. Hasil in-efisiensi teknis diperoleh dari pengolahan data dengan menggunakan perangkat lunak Frontier 4.1. Variabel bebas yang berpengaruh terhadap inefisiensi teknis dalam penelitian ini yaitu Survival rate, jumlah induk patin, rata-rata umur pekerja, rata-rata pengalaman pekerja dan rata-rata pendidikan pekerja.

Tahel 3. Pendugaan ParameterMLEModel In-efisiensi Teknis Pandawa Lima Fisheries Farm

\begin{tabular}{|c|c|c|}
\hline Variabel & Koefisien & t-hitung \\
\hline Intersep & 1,53 & $1,8 * *$ \\
\hline Survival Rate $\left(\mathrm{Z}_{1}\right)$ & $-0,99$ & $-1052,4^{*}$ \\
\hline Jumlah Induk $\left(Z_{2}\right)$ & $-0,002$ & $-1,38 * * *$ \\
\hline Rata-Rata Umur Pekerja $\left(Z_{3}\right)$ & $-0,86$ & $.5,5^{*}$ \\
\hline Rata-Rata Pengalaman Pekerja $\left(Z_{4}\right)$ & $-0,54$ & $-4,86^{*}$ \\
\hline Rata-RataPendidikanPekerja $\left(\mathrm{Z}_{j}\right)$ & 2,27 & $4,46^{*}$ \\
\hline
\end{tabular}

Berdasarkan Tabel 3 dapat diketahui bahwa nilai koefisien dari Survival rate benih patin adalah 0,99 ke arah negatif, sedangkan nilai $\mathrm{t}$ hitung sebesar 1052,4 yaitu lebih besar dari nilai t tabel pada taraf kesalahan $1 \%$ sebesar 2,756 yang menunjukan bahwa variabel Survival rate benih patin berpengaruh secara nyata pada in-efisiensi teknis.

Nilai koefisien dari variabel jumlah induk patin adalah 0,002 ke arah negatif. Hal ini menunjukan bahwa semakin tinggi jumlah induk patin maka akan meningkatkan produksi benih patin di
Pandawa Lima Fisheries Farm Bogor. Sedangkan nilai t hitung sebesar 1,38 yang menunjukkan bahwa jumlah induk patin berpengaruh nyata pada in-efisiensi teknis karena nilainya lebih besar dari nilai t tabel pada taraf kesalahan $20 \%$ sebesar 1,311.

Nilai koefisien dari Rata-Rata Umur Pekerja di Pandawa Lima Fisheries Farm Bogor adalah 0,86 ke arah negatif. Nilai $t$ hitung pada variabel Rata-Rata Umur Pekerja adalah 5,5. Nilai $t$ hitung lebih besar dari $\mathrm{t}$ tabel pada taraf kesalahan $1 \%$ sebesar 2,756 sehingga variabel Rata-Rata Umur Pekerja mempunyai pengaruh yang nyata dalam in-efisiensi teknis.

Nilai koefisien rata-rata pengalaman pekerja di Pandawa Lima Fisheries Farm Bogor adalah 0,54 ke arah negatif. Nilai t hitung pada variabel rata-rata pengalaman pekerja adalah 4,8. Nilai t hitung tersebut lebih besar dibandingkan nilai $t$ tabel pada taraf kesalahan $1 \%$ sebesar 2,756, sehingga variabel rata-rata pengalaman pekerja di Pandawa Lima Fisheries Farm berpengaruh nyata terhadap nilai in-efisiensi teknis.

Nilai koefisien dari rata-rata pendidikan pekerja di Pandawa Lima Fisheries Farm Bogor adalah 2,27 ke arah positif. Nilai t hitung pada variabel rata-rata pendidikan pekerja sebesar 4,46 atau lebih besar dari nilai t tabel pada taraf $1 \%$ yaitu 2,756, sehingga dapat disimpukan bahwa variabel rata-rata pendidikan pekerja berpengaruh nyata pada nilai in-efisiensi teknis.

\section{Pendapatan Usahatani Benih Ikan Patin}

Pendapatan usahatani dapat dihitung dengan mengetahui nilai selisih antara nilai penerimaan tunai dan biaya usahatani. Penerimaan usahatani dapat dihitung dengan perkalian antara harga output dan total produksi. Sedangkan biaya usahatani dapat dihitung dengan menjumlahkan antara biaya tetap dan biaya variabel. Jumlah pendapatan 
usahatani Pandawa Lima Fisheries Farm Bogor dapat dilihat pada Tabel 4.

Takel.4, Pendapatan Usaha Pambenihan Ikan Patin Pandawa Lima Fisharias Farm Bogor dalam 30 Siklus Produksi

\begin{tabular}{|l|c|}
\hline \multicolumn{1}{|c|}{ Keterangan } & Nilai (Rp) \\
\hline Total Penerimaan & $7.888 .281,25$ \\
\hline Biaya Variabel & $5.726 .937,5$ \\
\hline Biaya Tetap & 1.310 .000 \\
\hline Total Biaya & $7.036 .937,5$ \\
\hline Total Pendapatan & $\$ 51,343,75$ \\
\hline Ratio RC & 1,12 \\
\hline
\end{tabular}

Berdasarkan Tabel 4 dapat diketahui bahwa jumlah penerimaan pada pembenihan patin di Pandawa Lima Fisheries Farm sebesar Rp. 7.888.281,25 setiap siklusnya, sedangkan jumlah biaya total pada pembenihan patin sebesar Rp. 7.036.937,5 setiap siklusnya. Selanjutnya, terlihat bahwa jumlah pendapatan usahatani pembenihan ikan patin di Pandawa Lima Fisheries Farm yaitu sebesar Rp. 851.343,75 setiap siklusnya, sedangkan hasil analisis $\mathrm{R} / \mathrm{C}$ yang diperoleh adalah 1.12.

\section{KESIMPULAN DAN SARAN}

\section{Kesimpulan}

Berdasarkan hasil penelitian dapat disimpulkan bahwaHasil analisis pendapatan produksi benih ikan patin Pandawa Lima Fisheries Farm Bogor menunjukan bahwa pendapatan usahatani bernilai positif dengan nilai sebesar Rp. 851.343,75 dan analisis $\mathrm{R} / \mathrm{C}$ memiliki nilai lebih dari satu yang bersifat positif dengan nilai sebesar 1,12. Nilai R/C yang diperoleh menunjukan bahwa setiap perusahaan mengeluarkan biaya usahatani sebesar Rp. 1.000 dan untuk melakukan produksi benih patin, maka Pandawa Lima Fisheries Farm dapat memperoleh penerimaan tunai sebesar Rp.
1.120 setiap siklus. Dengan demikian usaha produksi benih ikan patin Pandawa Lima Fisheries Farm menguntungkan bagi perusahaan.

\section{Saran}

Untuk mengurangi nilai in-efisiensi teknis maka perlu adanya peningkatan nilai Survival rate benih patin, peningkatan jumlah induk patin, meningkatkan rata-rata umur pekerja dan pengalaman pekerja, sehingga dapat meningkatkan nilai efisiensi teknis dan produksi benih ikan patin. Perlu adanya peningkatan jumlah larva patin, berat indukan patin dan tenaga kerja supaya perusahaan dapat meningkatkan produksi benih patin. Peningkatan jumlah tersebut harus dibarengi dengan peningkatan kualitas supaya hasil benih ikan patin yang didapat memiliki kualitas yang baik.

\section{DAFTAR PUSTAKA}

Badan Pusat Statisik Nasional Provinsi Jawa Barat, Konsumsi Ikan, Bandung, BPS Jawa Barat, 2015.

Dewi Mira Ayu Rushita, Analisis Efisiensi Teknis Penggunaan Faktor Produksi pada Usahatani Jagung (Zea Mays), [Skripsi], Malang, Universitas Brawijaya, Fakultas Pertanian, Jurusan Agribisnis, 2012.

Direktoral Jenderal Perikanan Budidaya, Laporan Tahunan Direktoral Produksi Tahun 2013, Direktoral Jenderal Perikanan Budidaya, Jakarta, Kementerian Kelautan dan Perikanan, 2014.

Faried Wijaya, Seri Pengantar Ekonomika Mikro, Yogyakarta, BPFE, 1991 
Ghozali Imam, Aplikasi Analisis Multivariate dengan Program SPSS, Semarang, Badan Penerbit Universitas Diponegoro, 2005

Hardjamulia Atmadja dan Atmawinata Suherman, "Teknik Hipofisasi Beberapa Jenis Ikan Air Tawar" dalam Prosiding Lokakarya Nasional Teknologi Tepatguna Bagi Pengembangan Perikanan Budidaya Air Tawar, Bogor, Lembaga Penelitian Perikanan Darat, 1980.

Hardjamulia Atmadja, T.H. Prihadi dan Subagyo, Pengaruh Salinitas Terhadap Pertumbuhan dan Kelangsungan Hidup Ikan Jambal Siam (Pangasius sutchi), Bogor, Lembaga Penelitian Perikanan Darat, 1987.

Hasanudin, Efisiensi Teknis dan Pendapatan Usahatani Pembenihan Ikan Patin di Kota Metro Lampung, [Skripsi], Bogor, Insititut Pertanian Bogor, Fakultas Ekonomi dan Manajemen, Departemen Agribisnis, 2011.

Hernanto Fadholi, Ilmu Usahatani, Jakarta, Penerbit PT Penebar Swadaya, 1989.

Jangkaru Zulkifli, Djajadiredja Rustami, dan Oemiaraso Soedjito, "Mekanisasi Dalam Usaha Peningkatan Dayaguna Air Tawar Untuk Budidaya Ikan Secara Intensif' dalam Prosiding Lokakarya Nasional Teknologi Tepatguna Bagi Pengembangan Perikanan Budidaya Air Tawar, Bogor, Lembaga Penelitian Perikanan Darat Bogor, 1980.

Jangkaru Zulkifli, Pembesaran Ikan Air Tawar di Berbagai Lingkungan Pemeliharaan, Jakarta, PT Penebar Swadaya, 1995.
Khairuman, Kiat Mengatasi Permasalahan Praktis Budidaya Patin Secara Intensif, Depok, AgroMedia Pustaka, 2002.

Kurniasari Panca, Analisis Efisiensi dan Faktor-Faktor yang Mempengaruhi Produksi Industri Kecil Kabupaten Kendal, [Skripsi], Semarang, Universitas Diponegoro, Fakultas Ekonomi, Jurusan Ilmu Ekonomi Studi Pembangunan, 2011.

Kusumah Wijaya dan Dwitagama Dedi, Mengenal Penelitian Tindakan Kelas, Jakarta, PT Indeks, 2011.

Mahyuddin Kholis, Panduan Lengkap Agribisnis Patin, Jakarta, Penebar Swadaya, 2010.

Masyhuri, Ekonomi Mikro, Malang, UIN Malang Press, 2007.

Miller Roger LeRoy dan Roger E. Meiners, Jakarta, Teori Mikroekonomi Intermediate, penerjemah Haris Munandar, PT. Raja Grafindo Persada, 2000 .

Moleong Lexy, Metode Penelitian Kualitatif, Bandung, PT Remaja Rosdakarya, 2002.

O’Sullivan Arthur dan M. Sheffrin Steven, Economics: Principles in Action, New Jersey, Prentice Hall, 2005.

Pandawa Lima Fisheries Farm, Laporan Produksi Benih Patin, Bogor, Pandawa Lima Fisheries Farm, 2012

Perangin-angin K, Pembenihan Ikan Jambal Siam, Yogyakarta, Kanisius, 2003. Pusluh, Materi Penyuluhan, Jurnal, Penerbit Pusat Penyuluhan Kelautan dan Perikanan, 2011. 
Puspita dan Wiyono Ahmad, Budidaya Patin Cepat Panen, Jakarta, Penerbit Infra Pustaka, 2014.

Rasul Agung Abdul, Wijiharjono Nuryadi, dan Setyowati Tupi, Ekonomi Mikro Edisi 2, Jakarta, Penerbit Mitra WacanaMedia, 2013.Soekartawi, Analisis Usahatani, Jakarta, Penerbit UIPress, 2006.

Soekartawi, Teori Ekonomi Produksi Dengan Pokok Bahasan Analisis Fungsi Cobb Douglas, Jakarta, Penerbit PT. Raja Grafindo Persada, 2003.

Statistik Kementerian Kelautan Perikanan, Volume Produksi dan Tingkat Konsumsi Ikan Nasional, (http://www.statistik.kkp.go.id), Diakses 6 September 2014), 2014.

Sugiyono, Metode Penelitian Kuantitatif Kualitatif dan R\&D, Bandung, Alfabeta, 2008.

Sugiyono, Memahami Penelitian Kualitatif, Bandung, Alfabeta, 2012.

Witono Adiyoga, Beberapa Alternatif Pendekatan untuk Mengukur Efisiensi dan Inefisiensi dalam Usahatani, Jakarta, Jurnal Informatika Pertanian, 1999.

* Alamat Korespondensi:

lilis.imamah@uinjkt.ac.id 